\title{
KEBIJAKAN TENTANG INTEGRASI AKTIVITAS PENANGKAPAN DENGAN PEMBUDIDAYAAN UNTUK KEBERLANJUTAN SUMBERDAYA IKAN SIDAT (Anguilla spp) DI DAS POSO
}

\section{POLICY ON INTEGRATION OF CAPTURE AND CULTIVATION ACTIVITIES TO MAINTAIN Anguillaspp SUSTAINABILITY IN POSO WATERSHED}

\author{
Navy Novy Jefry Watupongoh ${ }^{1}$ dan Krismono ${ }^{2}$ \\ ${ }^{1}$ Pusat Penelitian Pengelolaan Perikanan dan Konservasi Sumber Daya Ikan \\ ${ }^{2}$ Balai Penelitian Pemulihan dan Konservasi Sumber Daya Ikan \\ Teregistrasi I tanggal: 13 November 2014; Diterima setelah perbaikan tanggal: 24 Maret 2015; \\ Disetujui terbit tanggal: 02 April 2015 \\ E-mail: navy.watupongoh@gmail.com
}

\begin{abstract}
ABSTRAK
Daerah Aliran Sungai (DAS) Poso merupakan salah satu daerah penangkapan ikan sidat, memiliki luas $1.101,87 \mathrm{~km}^{2}$ dan panjang $\pm 68,70 \mathrm{~km}$. Ikan sidat di perairan Poso merupakan komoditas perikanan yang memiliki nilai ekonomis tinggi (harga Rp.100.000,-/kg) dan menjadi primadona hasil tangkapan. Ikan sidat yang hidup di DAS Poso terdapat 5 jenis, yaitu $A$. marmorata, A. bicolor pasific, A. celebensis, A. borneensis dan A. interioris. Saat ini telah terjadi penurunan produksi induk maupun glass eel ikan sidat di DAS Poso disebabkan oleh penangkapan yang belum memperhatikan faktor kelestarian dan keberlajutannya seperti penangkapan yang berlangsung tidak hanya pada saat induk ikan sidat yang beruaya ke laut tapi juga glas eel yang menuju ke danau. Pembangunan PLTA pada alur Sungai Poso mengganggu ruaya ikan sidat yang mengakibatkan terputusnya ruaya ikan sidat dari dan ke Danau Poso yang berakibat hilangnya ikan sidat di Danau Poso. Berkaitan dengan permasalahan ini maka populasi sumberdaya ikan sidat perlu dijaga keberlanjutannya dengan cara mengintegrasikan aktivitas penangkapan dengan pembudidayaan, oleh karena itu diperlukan kebijakan yang menetapkan peraturan terkait dengan penangkapan yang menggunakan alat tangkap ramah lingkungan serta diintegrasikan dengan pembudidayaan. Kajian kebijakan ini bertujuan untuk merumuskan kebijakan tentang integrasi aktivitas penagkapan dengan pembudidayaan untuk berkelanjutan ikan sidat di DAS Poso.
\end{abstract}

KATA KUNCI: Integrasi, penangkapan, budidaya, ikan sidat, DAS Poso.

\begin{abstract}
The watershed of Poso River is one of anguillid eel fishing areas. This watershed has an area of $1,101.87 \mathrm{~km} 2$ and length \pm 68.70 miles. The anguillid eel is a commodity that has a high economic value (IDR 100,000 / kg) and has an excellent catches. There are 5 types of eels that live in the watershed of Poso, they are: A. marmorata, A. bicolor pacific, A. celebensis, $A$. borneensis and $A$. interioris. The decreased production of anguillid parent and glass eels in the watershed of Poso is a result from the capture that had not yet noticed the preservation and sustainability factors, such as the capture that took place not only at the time of sea migration phase (the parents), but also on the lake migration phase (the glass eels), as well as Poso river damming for hydropower purpose. The decrease in the production of glass eel and parent eels in the watershed of Poso is also caused by fishing activities that have not been integrated with cultivation. There is a need of a regulation for fishing by using environmentally friendly fishing gears as well as the integration with cultivation. This paper aims to formulate policy on integration of capture and cultivation for sustainable catch of anguillid eels in the watershed of Poso.
\end{abstract}

\section{KEYWORDS: Integration, catching, farming, eel, Poso watershed}

\section{PENDAHULUAN}

Ikan sidat atau sogili di DAS Poso merupakan ikan yang memiliki nilai ekonomis penting (Rp. 100.000,-/ $\mathrm{kg}$ ) dan permintaan ikan tersebut di pasaran juga cukup tinggi antara lain ke Jepang, Cina, Taiwan, Jerman, Belanda, Perancis dan Denmark (Krismono, 2011).
Pada tahun 2012 Jepang melalui asosiasi warga Jepang yang ada di Indonesia mengharapkan pasokan ikan sidat dari Indonesia sebanyak 40 ton per tahun. Sidat merupakan jenis ikan yang memiliki karakteristik unik dengan melakukan ruaya (migrasi) untuk keperluan reproduksinya ke laut dalam. Setelah melakukan pemijahan, larva sidat akan ke perairan 
tawar melalui muara-muara sungai untuk selanjutnya tumbuh dan berkembang sampai ukuran dewasa pada habitat perairan tawar seperti sungai dan danau (Krismono, 2010).

Daerah Aliran Sungai (DAS) Poso merupakan salah satu daerah penangkapan ikan sidat dengan luas $\pm 1.101,87 \mathrm{~km}^{2}$ dan panjang $\pm 68,70 \mathrm{~km}$ (Ishak, 2010). Ikan sidat yang hidup di DAS Poso sebanyak 5 jenis, yaitu $A$. marmorata, $A$. bicolor pasific, $A$. celebensis, $A$. borneensis, dan $A$. interioris(Sugeha et al., 2008). Ikan sidat termasuk famili Anguillidae merupakan ikan katadromus yaitu ikan yang hidup di perairan tawar (sungai/danau), bemigrasi ke laut untuk melakukan pemijahan dan setelah itu kembali lagi ke perairan tawar untuk melanjutkan siklus hidupnya. Memiliki beberapa stadia perkembangan dalam siklus hidupnya yaitu: leptochepalus, metamorphosis, glass eelatau elver, sidat dewasa (yellow eel) dan silver eel (sidat dewasa atau matang gonad). Peran DAS Poso sangat penting dalam mendukung siklus hidup ikan sidat tersebut sebagai habitat ruaya ikan sidat.

Potensi ikan sidat di muara Poso diperkirakan sekitar 50.000 ekor glass ee/pertahun dan tertangkap sekitar 15.000 ekor/tahun, sementara glass eel yang beruaya ke sungai 35.000 ekor/tahun (Krismono, 2011). Penelitian sebelumnya sekitar 36.000 ekor/ tahun (Anonim, 2009). Selanjutnya hasil penelitian tahun 2011-2012 potensi induk ikan sidat terdapat 6.000 ekor/tahun dan tertangkap 3.000 ekor/tahun dengan menggunakan bubu maupun sero (wayamasapi) dan sekitar 2.000 ekor/tahun tertangkap di sungai dan muara, sedangkan induk yang ke laut sekitar 1.000 ekor/tahun. Hasil penelitian sebelumnya potensi induk sekitar 9.000 ekor/tahun (Husnah et al., 2008). Sarnita (1973) mengemukakan hasil penelitiannya bahwa estimasi produksi ikan sidat induk pada tahun 1970-an mencapai 22 ton/tahun.

Hasil-hasilpenelitian di atas menunjukkan adanya penurunan produksi glass ee/ maupun induk ikan sidat di DAS Poso sebagai akibat dari aktivitas penangkapan secara terus-menerus tanpa memperhatikan keberlanjutan dan kelestarian populasi ikan sidat seperti melakukan penebaran kembali benih ikan sidat di DAS Poso. Penangkapan tidak hanya dilakukan pada waktu ikan bermigrasi ke laut namun juga sebaliknya pada saat elver menuju ke danau.

Selain aktivitas penangkapan yang tidak bijaksana, keberadaan pembangunan PLTA pada alur Sungai Poso mengganggu ruaya ikan sidat. Hal ini mengakibatkan terputusnya ruaya ikan sidat dari dan ke Danau Poso yang pada akhirnya akan berakibat hilangnya ikan sidat di Danau Poso. Benih sidat seringkali tidak sampai ke habitat perairan tawar dengan baik disebabkan adanya halangan pada aliran sungai (bendungan, jeram dan sebagainya) yang dapat pula menghambat migrasi sidat dewasa ke laut, mortalitas juga terjadi apabila sidat terbawa pada aliran air pada mesin pembangkit listrik apabila tidak dilengkapi dengan jalan ikan (fish way) untuk tujuan ruaya.

Selain permasalahan di atas, penurunan produksi glass eel maupun induk ikan sidat di DAS Poso disebabkan oleh aktivitas penangkapan belum dintegrasikan dengan pembudidayaan. Aktivitas penangkapan ikan sidat selama ini dilakukan secara terus menerus tanpa mempertimbangkan aspek kelestariaan dan keberlanjutan sumber daya ikan sehingga menyebabkan penurunan produksi.

Pengaturan penangkapan perlu diatur dengan menggunakan alat sederhana dan ramah lingkungan yang dintegrasikan dengan pembudidayaan. Setiap penangkapan ikan sidat oleh nelayan penangkap yang dilakukan di DAS Poso dan menghasilkan hasil tangkapan yang dikonversikan dengan kilogram yang sudah ditetapkan oleh Pemda setempat berupa kebijakan lokal, maka nelayan tersebut harus menggantikan hasil tangkapannya dengan jumlah benih yang dikonversikan dengan kilogram dan benih tersebut langsung ditebarkan oleh nelayan tersebut di sekitar wilayah tangkapannya. Keterpaduan aktivitas nelayan penangkap dengan pembudidayaan tersebut akan mendorong kelestarian dan keberlanjutan populasi ikan sidat di DAS Poso.

Berdasarkan permasalahan di atas maka tujuan kajian kebijakan adalah untuk merumuskan:

Kebijakan tentang integrasi aktivitas penangkapan dengan pembudidayaan ikan sidat di DAS Poso yang lestari dan berkelanjutan.

Strategi pengaturan keseimbangan aktivitas penangkapan yang semaikin tinggi dengan pembudidayaan (pembenihan/pembesaran) di sekitar DAS Poso.

\section{KONDISI SAAT INI \\ Jenisdan Siklus Hidup Ikan Sidat}

DAS Poso termasuk perairan Sulawesi yang terdiri atas Sungai Poso yang mengalir dari Danau Poso di Tentena sampai muaranya di Teluk Tomini serta anakanak sungainya merupakan habitat dan kawasan ruaya ikan sidat. Masyarakat setempat memanfaatkan Sungai Poso sebagai kawasan penangkapan ikan dan sumber air masyarakat sekitar. Muara Sungai Poso merupakan muara yang paling 
besar di DAS Poso dan di sekitarnya terdapat 4 sungai kecil utama yang merupakan kawasan ruaya ikan sidat. Bagian hulu Sungai Poso adalah Danau Poso dengan luas 32.320 ha, kedalaman maksimum 450 $\mathrm{m}$ dengan ketinggian $485 \mathrm{~m}$ di atas permukaan laut, sedangkan anak-anak Sungai Poso ketinggiannya sekitar $100 \mathrm{~m}$ di atas permukaan laut (Lehmusluoto \& Machbub, 1997).

Salah satu jenis ikan sidat yang hidup di DAS Poso yaitu ikan sidat marmorata atau sogili merupakan jenis sidat dengan kualitas terbaik dan memiliki nilai ekonomis penting sehingga permintaan ikan tersebut di pasaran juga cukup tinggi.

Ikan sidat mempunyai siklus hidup reproduksi yang unik dan rumit yaitu ikan sidat dewasa yang telah matang gonad akan bermigrasi ke laut dan berpijah di kedalaman laut lebih dari $300 \mathrm{~m}$. Setelah telur menetas, larva sidat akan terbawa oleh arus laut dan kembali keperairan pantai. Kurang lebih sampai berumur 5-7 bulan larvaikan menjadi glass ee/yang transparan dan migrasi ke perairan estuari, sungai dan berkembang menjadielver. Elver akan tumbuh dan berkembang menjadi sidat dewasa di perairan tawar dan estuari selama kurang lebih 1-3 tahun, selanjutnya setelah matang gonad akan kembali ke laut untuk memijah.

\section{Ukuran dan Berat}

Berdasarkan hasil penelitian Samliok Ndobe (2010), kisaran panjang total glass eel ikan sidat Anguilla marmorata yang tertangkap selama bulan Januari-April berkisar antara 4,1-5,0 cm dengan modus distribusi frekuensi berada pada kelas 4,5$4,8 \mathrm{~cm}$. Nilai-nilai kisaran ukuran mengalami pergeseran pada setiap bulan. Berdasarkan frekuensi panjang total glass eel tersebut diperoleh sebanyak 10 struktur ukuran panjang total. Data tersebut dapat digunakan sebagai acuan atau dasar pengelompokkan berdasarkan ukuran panjang total benih ikan sidat (glass eel) Anguilla marmorata dalam upaya pengembangan teknologi budidaya, baik tahap pendederan untuk memproduksi ukuran fingerling siap tebar (ukuran berat \pm 10 gram dan/atau panjang total $\pm 10 \mathrm{~cm}$ ), maupun tahapan pembesaran ukuran konsumsi yaitu 250 - 300 gram atau lebih.

Kisaran berat tubuh Anguilla marmorata yang tertangkap selama bulan Januari - April adalah 0,04 0,15 gram dengan modus distribusi frekuensi berada pada kelas ukuran berat 0,05 - 0,10 gram. Berdasarkan frekuensi berat glass eel tersebut juga diperoleh sebanyak 10 struktur ukuran berat tubuh. Sama halnya dengan ukuran panjang total, data tersebut juga dapat digunakan sebagai acuan atau dasar pengelompokkan berdasarkan ukuran berat tubuh benih ikan sidat (glass eel) Anguilla marmorata dalam upaya pengembangan teknologi budidaya baik tahap pendederan untuk memproduksi ukuran fingerling siap tebar dengan ukuran berat \pm 10 gram dan/atau panjang total $\pm 10 \mathrm{~cm}$ maupun tahapan pembesaran ukuran konsumsi dengan ukuran 250-300 gram atau lebih (Samliok Ndobe, 2010).

Hasil penelitian Husnah et al. (2008) menunjukkan bahwa ikan sidat di Danau Poso tereksploitasi sejak fase elver atau glass eel, yellow eel dengan ukuran 20-60 cm untuk silver eel dengan ukuran di atas 60 $\mathrm{cm}$.

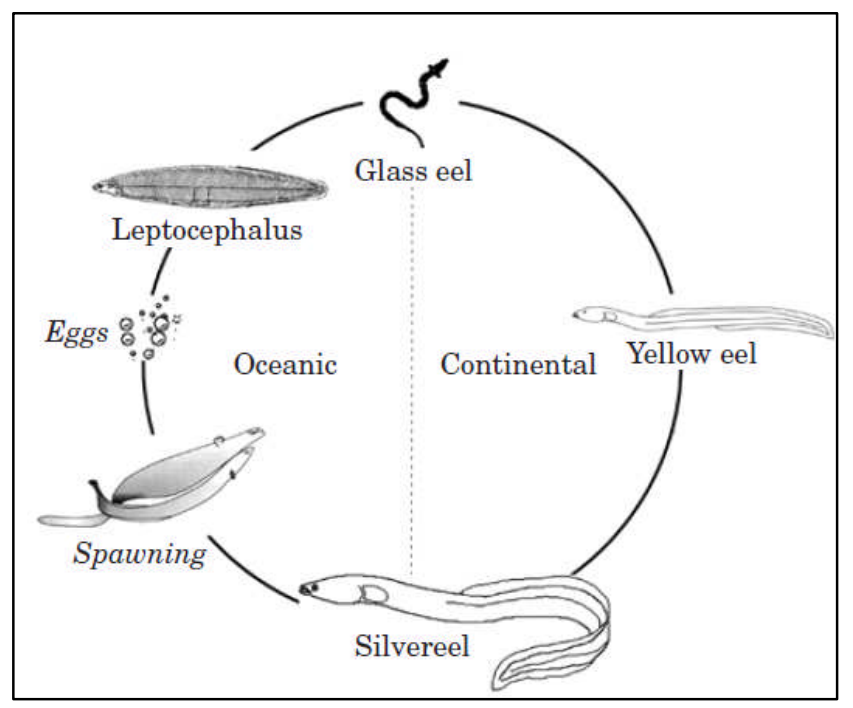

Gambar 1. Siklus hidup ikan sidat Eropa, Anguilla anguilla (Dekker, 2000).

Figure 1. The life cycle of the European eel, Anguilla anguilla (Dekker, 2000). 


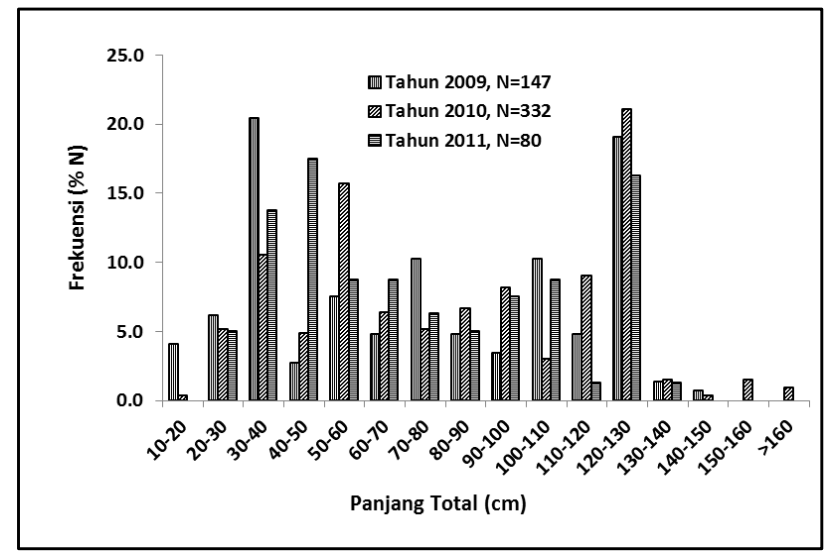

Gambar 2. Distribusi ukuran ikan sidat yang tertangkap wayamassapi pada tahun 2010 (Krismono \& Kartamihardja, 2012).

Figure 2. Eels size distribution caught by "wayamassapi" in 2010(Krismono \& Kartamihardja, 2012).

\section{Eksploitasi Sumberdaya Ikan Sidat}

Estimasi produksi ikan sidat di Danau Poso pada tahun 1980 , produksi ikan sidat meningkat mencapai 41,5 ton, namun pada tahun 1998 menurun menjadi 30,5 ton (Haryani \& Hehanussa, 2000). Pada periode tahun 2004-2005, hasil tangkapan ikan sidat di Danau Poso diperkirakan sebesar 22-54 ton atau sekitar 40\% dari rata-rata hasil tangkapan total ikan di danau tersebut (Husnah et al., 2008).

Hasil tangkapan ikan sidat berdasarkan total tangkapan lebih banyak tertangkap di muara Poso dibandingkan lokasi penelitian lainnya (Gambar 3).
Berdasarkan beratnya, hasil tangkapan ikan sidat lebih besar di Tentena. Data tersebut menunjukkan bahwa ikan sidat yang tertangkap di Tentena mempunyai ukuran yang jauh lebih besar dibandingkan lokasi lainnya, dimana dari 53 ekor ikan sidat yang tertangkap berat totalnya mencapai 168.850 gram sedangkan di muara Poso dengan total tangkapan 83 ekor beratnya hanya 83.270 gram. Rata-rata berat ikan sidat yang tertangkap di muara Poso, Pandiri dan Sulewana berkisar antara 1.0031.696 gram/ekor sedangkan di Tentena rata-rata 3.186 gram/ekor ( \pm 3 kali lebih berat dibandingkan ikan sidat yang tertangkap di Muara-Sulewana).

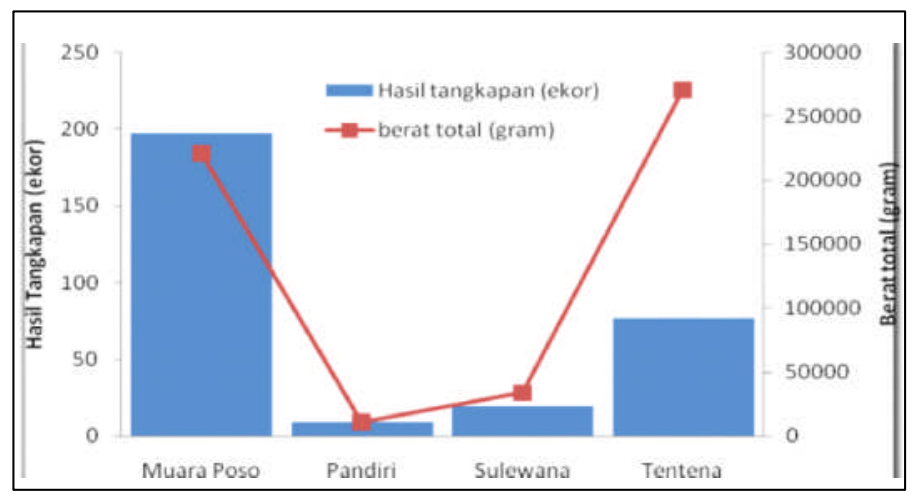

Gambar 3. Hasil tangkapan ikan sidat di DAS Poso tahun 2010-2011 (Krismono \& Kartamihardja, 2012). Figure 3. Composition of Eel catches at Poso River (Krismono \& Kartamihardja, 2012)

Sidat-sidat yang tertangkap adalah sidat yang beruaya ke laut, hal ini karena alat tangkap yang digunakan yaitu berupa perangkap wayamassapi yang diarahkan ke hulu sungai (Sutardjo \& Machfudz, 1974). Sedangkan berdasarkan data tahun 1990-1995, produksi rata-rata sidat di perairan ini, pada puncak musim penangkapan yaitu antara Januari - Juni (musim hujan) berkisar antara 1,75-9,83 ton/bulan, atau rata-rata 5,50 ton/bulan.
Produksi sidat saat ini masih mengandalkan hasil tangkapan. Perlu kemudian dipikirkan teknologi yang sesuai untuk membesarkan sidat muda (elver) karena potensi rekrut yang besar. Estimasi perhitungan produksi sidat dapat mencapai 1.000 ton/tahun bila berhasil dibesarkan sebanyak $20 \%$ dari sidat muda yang masuk keperairan Poso, degan rata-rata berat per ekor $3 \mathrm{~kg}$ dengan masa pemeliharaan 3 tahun. (Triyanto et al., 2008). 
Pada periode tahun 2004-2005, hasil tangkapan ikan sidat di Danau Poso diperkirakan sebesar 22-54 ton atau sekitar $40 \%$ dari rata-rata hasil tangkapan total ikan di danau tersebut (Husnah et al., 2008). Sementara itu, pada periode 2008-2010 produksi hasil tangkapan ikan sidat di DAS Poso mengalami peningkatan sebesar $1,5 \%$. Pada tahun 2008 , hasil tangkapan ikan sidat $\pm 9,1$ ton dan pada tahun 2010 mencapai 11,3 ton. Kenaikan produksi tangkapan ikan sidat ini diduga disebabkan oleh bertambahnya jumlah nelayan yang pada tahun 2010 , sebanyak 116 orang nelayan yang semula hanya berjumlah sekitar 50 nelayan pada tahun 2005 . Jumlah nelayan perairan umum daratan di Kabupaten Poso tercatat sebanyak 476 nelayan dengan jumlah hasil tangkapan sekitar 70,1 ton (Anonim, 2009).

Hasil penelitian tahun 2010-2011 menunjukkan bahwa potensi ikan sidat sekitar 50.000 .000 ekor glass eel/tahun dan tertangkap sekitar 15.000 .000 ekor/ tahun, maka glass eel yang beruaya ke sungai 35.000.000 ekor/tahun, sedangkan untuk induk hasil penelitian potensi induk 6.000 ekor/tahun dan tertangkap 3.000 ekor/tahun tertangkap di Wayamassapi dan sekitar 2.000 ekor/tahun tertangkap di sungai serta muara, maka induk yang ke laut sekitar 1.000 ekor/tahun. Pada tahun yang sama, hasil tangkapan sidat di Danau Poso mencapai 15 ton dan potensi anak sidat di muara Sungai Poso \pm 30 juta ekor/tahun sedangkan jumlah anak ikan sidat yang tertangkap \pm 15 juta ekor/tahun. Hasil tangkapan ikan sidat induk di Tentena telah mengalami penurunan dari 36 ton pada tahun 2004-2005 menjadi 25 ton pada tahun 2010-2011. Demikian pula, elver sidat di muara Sungai Poso telah mengalami penurunan dari 36.000.000 ekor pada tahun 2009 menjadi 35 juta ekor pada tahun 2012 (Krismono \& Kartamihardja, 2012).

Pada umumnya alat tangkap yang digunakan oleh nelayan untuk menangkap ikan sidat di DAS Poso yaitu menggunakan bubu, pancing, wayamassapi, seser dan setrum. Alat tangkap wayamassapi dan setrum dikhawatirkan mengganggu ruaya serta kelangsungan hidup ikan sidat. (Muryanto \& Sumarno, 2013).

Berdasarkan uraian di atas terkait dengan aktivitas penangkapan yang dilakukan oleh nelayan penangkap Ikan Sidat di DAS Poso mempunyai dampak terhadap pengurangan jumlah populasi yang disebabkan penangkapan berlebih terhadap benih sidat dalam bentuk glass eel, dan banyaknya wayamassapi yang menangkap induk ikan sidat.

\section{REGULASI}

Upaya untuk mengatur pengelolaan dan konservasi sumberdaya ikan sidat di DAS Poso sudah tertuang pada Peraturan Daerah Kabupaten Poso berdasarkan amanat perundang-undangan yang merupakan pelaksanaan ketentuan perundangundangan yang berlaku diantaranya, yaitu:SKMenteri Pertanian No: 214/Kpts/Um/V/1973 tentang pelarangan pengeluaran ikan sidat dari Negara RI; Peraturan Menteri KPNo: 18/Men/2009 yang antara lain berisi ekspor ikan sidat yang diperbolehkan pada ukuran benih ikan sidat panjang $35 \mathrm{~cm}$ dan/atau berat sampai $100 \mathrm{gram} / \mathrm{ekor}$ dan/atau berdiameter sampai 2,5 cm; PERMEN KPNo: 19/Men/2012 yang antara lain mengatur ukuran benih ikan sidat yang dapat di ekspor berukuran berat paling kecil 150 gram; dan Perda Kabupaten Poso No: 8 Tahun 2012 tentang Rencana Tata RuangWilayah Kabupaten Poso Tahun 2012-2032 yang menentukan wilayah Sungai Tomasa adalah kawasan konservasi/lindung untuk ikan sidat.

\section{AKTIVITAS PEMBUDIDAYAAN}

Sampai saat ini upaya pembenihan buatan telah dilakukan oleh para peneliti di Jepang sejak tahun 1974, walaupun sudah berhasil namun masih belum membuahkan hasil yang memuaskan untuk skala produksi masal. Sehubungan dengan siklus reproduksi yang luar biasa rumit, sehingga benih sidat belum dapat dihasilkan dari pembenihan, melainkan umumnya didapatkan dari alam yaitu dalam bentuk elveryang bermigrasi dari perairan laut ke tawar. Oleh karena itu, untuk keperluan budidaya, sumber benih sidat (elver) umumnya ditangkap di muara sungai dan atau badan sungai. Masalah yang dihadapi oleh pembudidaya ikan sidat di Indonesia adalah masalah daya saing yang ketat dengan negara produsen lainnya.

Pemilihian lokasi budidaya sidat menjadi penting mengingat berdasar siklus hidupnya sidat jantan dan sidat betina akan berpindah dari sungai atau danau menuju laut untuk melakukan perkawinan di kedalaman 400-500 m. Setelah perkawinan induk sidat tersebut akan mati. Dalam budidaya sidat ada beberapa tahapan yang bisa digarap, yakni pembesaran sidat muda berukuran 3-5 gram menjadi 8-10 gram yang membutuhkan waktu 3 bulan. Selanjutnya pembesaran sidat menjadi ukuran konsumsi 250-300 gram yang membutuhkan waktu hingga 10 bulan. Selama ini sidat banyak ditemukan dan dibudidayakan warga sekitar Danau Poso. 


\section{KEBIJAKAN DAN STRATEGI KEBERLANJUTAN SUMBER DAYA IKAN SIDAT DI DAS POSO}

\section{Kebijakan}

Konsepsi penguatan kebijakan pengelolaan sumber daya ikan sidat di DAS Poso pada dasarnya mengacu kepada kondisi pengelolaan pada saat ini yang dihadapkan kepada kondisi pengelolaan yang diharapkan dapat dicapai. Konsepsi yang dimaksud disini meliputi perumusan kebijakan dan strategi yang tepat untuk membangun pengelolaan sumber daya ikan sidat di DAS Poso. Kebijakan atau policyadalah suatu ketetapan yang memuat prinsip-prinsip untuk mengarahkan cara-cara bertindak yang dibuat secara terencana dan konsisten dalam mencapai tujuan tertentu(Arikunto, 2005).

Selanjutnya, dengan memperhatikan cakupan dimensi tersebut diatas, dapat dielaborasi arah dari pengelolaan sumber daya ikan sidat di DAS Poso yang lestari dan berkelanjutan dengan mengintegrasikan aktivitas penangkapan dan pembudidayaan. Contoh studi kasus, pemerintah China menerapkan peraturan tentang perlindungan tanaman pohon di negaranya, apabila ada seseorang menebang 1 pohon maka orang tersebut harus mengganti dengan menanam 10 pohon baru di hutan sehingga dengan demikian populasi pohon di hutan akan bertambah secara signifikan dan ekosistemnya akan terjaga dengan baik (De Murger et al., 2009).

Studi kasus ini dapat dianalogikan dengan aktivitas penangkapan oleh nelayan penangkap dan pembudidayaan ikan sidat di DAS Poso. Hal ini perlu ada kebijakan yang mengatur tentang pengitegrasian akivitas/kegiatan nelayan penangkap dengan pembudidaya. Apabila ada seseorang nelayan menangkap $5 \mathrm{~kg}$ ikan sidat, maka nelayan tersebut harus mengganti hasil tangkapannya dengan menebar $1 \mathrm{~kg}$ benih ikan sidat di danau atau sungai yang merupakan wilayah penangkapan nelayan tersebut. Benih ikan sidat tersebut didapatkan dengan membeli dari pembudidaya benih/pembesaran ikan sidat, sehingga benih hasil pembudidaya dapat termanfaatkan secara keberlanjutan dan terukur. Interaksi kegiatan ini mempunyai dampak mutualisme atau saling menguntungkan antara nelayan penangkap dan pembudidaya.

Berdasarkan arahan diatas dan mengacu kepada luasnya permasalahan yang harus ditangani, peluang dan kendala yang ada, serta kondisi yang diharapkan yang dihadapkan kepada kondisi saat ini, maka kebijakan yang diambil harus komprehensif, terintegrasi, terukur dan realistik, karena langkah yang diambil tersebut juga harus efektif atau dapat diimplementasikan secara nyata. Berdasarkan pemikiran tersebut, maka disarankan untuk menetapkan "Kebijakan tentang Integrasi Aktivitas Penangkapan dan Pembudidaya Untuk Keberlanjutan Sumber Daya Ikan Sidat di DAS Poso".

\section{Strategi}

Komponen strategi meliputi means (sumberdaya atau sarana dan prasarana), ends (tujuan atau sasaran) dan ways (cara dalam mencapai tujuan atau sasaran) (Naryadi, 2006).Kemudian, untuk perumusan strategi ini mengacu kepada kebijakan yang telah dirumuskan di atas, namun tetap berdasarkan kondisi nyata yang memungkinkan untuk dicapai. Strategi yang dirumuskan sebagai penjabaran lebih lanjut dari kebijakan, yaitu:

1) Strategi 1: Mengatur keseimbangan aktivitas penangkapan yang semakin tinggi dengan pembudidayan ikan sidat di DAS Poso.Tujuan dari strategi ini adalah untukmengatur aktivitas penangkapan yang dilakukan selama ini dengan diimbangi dengan penebaran kembali ikan sidat yang tertangkap dengan benih yang didapatkan dari pembudidayaan.Adapun sasaran yang hendak dicapai adalah: terjaganya keseimbangan usaha penangkapan oleh nelayan penangkap dengan pembudidayaan sumberdaya ikan sidat yang terintegrasi dan berkelanjutan; dan terjaganya jumlah populasi sumberdaya ikan sidat di DAS Poso.

2) Strategi 2: Mengembangkan pengelolaan sumberdaya ikan sidat di DAS Poso dengan prinsip "watershead zone integrated" dan ramah lingkungan, memiliki tujuan untuk membangun pola-pola usaha pemanfaatan sumberdaya ikan sidat yang saling mendukung dan terpadu serta harmoni dengan lingkungan DAS Poso. Adapun sasaran yang hendak dicapai adalah:terwujudnya usaha pemanfaatan sumberdaya ikan sidatyang terpadu dan berkelanjutan; dan terbentuknya wilayah DAS Poso hijau yang serasi dan harmoni dengan lingkungan.

3) Strategi 3: Meningkatkan dan memperkuat kawasan lindung DAS Poso sebagai daerah pengendali populasi sumberdaya ikan sidat dan berperan pula sebagai sumber pangan.Strategi ini bertujuan untuk menjaga keseimbangan ekosistem di DAS Poso dan sekaligus memelihara kelestarian sumberdaya ikan sidat yang dimanfaatakan sebagai sumber pangan. Sasaran yang ingin dicapai adalah terlindungnya wilayah DAS Poso dari gangguan atau kerusakan alam 
dan berkelanjutannya usaha pemanfaatan sumberdaya ikan sidat.

4) Strategi 4: Menjadikan lingkungan DAS Poso bersih dan menjadi sumber kehidupan masyarakat sekitar masa kini dan masa depan.Tujuan dari strategi ini adalah untuk meningkatkan kesadaran masyarakat di sekitar DAS Poso terhadap pentingnya menjaga lingkungan DAS Posobagi kehidupan dan kesehatan manusia, baik saat ini maupun yang akan datang. Wilayah DAS Poso sangat rentan akan kerusakan ekosistem di DAS Poso akibat lingkungan yang tidak terjaga, sehingga bila lingkungan tersebut dijaga dan dikelola dengan baik, maka akan menjadi sumber kehidupan ekonomi sebagian besar masyarakat dan DAS Poso juga merupakan sumber makanan sehat manusia. Jadi sudah semestinya DAS Poso menjadi sumber kehidupan masyarakat sekitar untuk masa kini dan masa depan sedangkan sasarannya adalah meningkatnya kesejahteraan dan kualitas hidup masyarakat, utamanya masyarakat sekitar DAS Poso.

5) Strategi 5: Melakukan pengkajian lebih dalam lagi berdasarkan penelitian tentang kondisi jalan ikan (fish way) yang telah dibangun di areal PLTA, terkait dengan kemampuan dan efektifitas fasilitas jalan ikan tersebut dalam mendukung ruaya ikan sidat dari Danau Poso ke laut untuk memijah, dan sebaliknya dari laut ke Danau Poso untuk berkembang menjadi dewasa. Tujuan dari strategi ini adalah untuk mesmastikan secara akurat dan terukur mengenai dampak dari kondisi jalan ikan yang ada di PLTA terhadap aktivitas ruaya ikan sidat. Sasaran yang ingin dicapai adalah terjaganya lingkungan jalur ruaya ikan sidat dari Danau Poso ke laut atau sebaliknya dari laut ke Danau Poso.

\section{KESIMPULAN DAN REKOMENDASI Kesimpulan}

Pupulasi ikan sidat di DAS Poso saat ini telah mengalami keterancaman kelestarian dan keberlanjutannya, hal ini tergambarkan seperti di bawah ini:

1. Wilayah DAS Poso sangat rentan akan kerusakan ekosistemnya, sehingga lingkungan tersebut harus dijaga dan dikelola dengan baik dan menjadi sumber kehidupan ekonomi masyarakat dan merupakan sumber makanan sehat manusia.

2. Produksi ikan sidat di DAS Poso telah terjadi penurunan jumlahnya, yang disebabkan oleh beberapa hal antara lain: penangkapan berlebih terhadap benih sidat dan glass eel, penangkapan intensif induk ikan sidat, dan pembendungan
Sungai Poso yang berpengaruhpada ruaya ikan sidat.

3. Aktivitas penangkapan ikan sidat di DAS Poso selama ini dilakukan secara terus menerus oleh nelayan penangkap tanpa melakukan penebaran kembali.

4. Belum ada kebiajakan lokal yang mengatur aktivitas penangkapan ikan sidat di DAS Poso yang diintegrasikan dengan pembudidayaan dalam rangka mendorong kelestarian dan keberlanjutan populasi ikan sidat di DAS Poso.

5. Jalur ruaya ikan sidat dari Danau Poso ke laut untuk memijah dan sebaliknya dari laut ke Danau Poso untuk berkembang menjadi dewasa telah terputus disebabkan adanya pembangunan PLTA pada alur Sungai Poso.

\section{Rekomendasi}

1. Untuk melindungi wilayah DAS Poso dari gangguan atau kerusakan alam dan berkelanjutannya usaha pemanfaatan sumberdaya ikan sidat maka perlu meningkatkan dan memperkuat kawasan lindung DAS Poso sebagai daerah pengendali populasi sumberdaya ikan sidat dan berperan pula sebagai sumber pangan.

2. Untuk meningkatkan produksi ikan sidat di DAS Poso maka populasinyaharus dijaga kelestarian dan keberlanjutannya sehingga perluditetapkan pengaturan penangkapan yang menggunakan alat sederhana dan ramah lingkungan yang diintegrasikan dengan pembudidayaan.

3. Untuk menjaga kelestarian dan keberlanjutan populasi sumber daya ikan sidat di DAS Poso, maka perlu mengatur keseimbangan aktivitas penangkapan yang semakin tinggi dengan pembudidayaan dan perlu ditetapkan menjadi kebijakan lokal oleh Pemerintah Provinsi/ Kabupaten Poso terkait dengan integrasi aktivitas penangkapan dan pembudidayaan ikan sidat di DAS Poso.

4. Untuk mewujudkan usaha pemanfaatan sumberdaya ikan sidat yang terpadu dan berkelanjutan dan terbentuknya wilayah DAS Poso hijau yang serasi dan harmoni dengan lingkungan, maka perlu mengembangkan pengelolaan sumberdaya ikan sidat di DAS Poso dengan prinsip "watershead zone integrated" dan ramah lingkungan.

5. Untuk menjaga lingkungan jalur ruaya ikan sidat dari Danau Poso ke laut atau sebaliknya dari laut ke Danau Poso, perlu melakukan pengkajian lebih dalam lagi berdasarkan penelitian tentang kondisi jalan ikan (fish way) yang telah dibangun di areal PLTA, terkait dengan kemampuan dan efektifitas 
fasilitas jalan ikan tersebut dalam mendukung ruaya ikan sidat.

\section{PERSANTUNAN}

Manuskrip ini disusun dalam rangka pemenuhan penulis sebagai peneliti tingkat pertama untuk menghasilkan karya tulis ilmiah yang rencananya akan diterbitkan pada Jurnal Kebijakan Perikanan Indonesia yang ada di Pusat Penelitian Pengelolaan Perikanan dan Konservasi Sumber Daya Ikan. Terima kasih diucapkan kepada Dr. Wijopriono, M.Sc sebagai pembimbing penulisan. Terima kasih diucapkan juga kepada Yudi Priatno, B.ENG, M.SE untuk kerjasamanya dalam mendorong dan mendukung hasil tulisan penulis untuk masuk dalam Jurnal P4KSI.

\section{DAFTAR PUSTAKA}

Anonim. 2009. Sidat (Anguilla sp) Komoditas Ekspor dari Sulawesi. Diunduh dari http:// tech.groups.yahoo.com/group/sidat/message/ 198? var=1 10 maret 2010 .

Arikunto, S. 2005. Manajemen Penelitian, edisi Revisi. Jakarta: Rineka Cipta.

Dekker, W. 2000. The fractal geometri of the eropean eel stock. ICES Journal of Marine Science, 57: p. 109-121

De Murger, S,. Yuanzhao, H \& Weiyong, Y. 2009. Forest Management Policies and Resource Balance in China An Assessment of the Current Situation. The Journal of Environment \& Development, 18 (1): 17-41.

Husnah, D. W. H. Tjahjo, A. S. Nastiti, D. Oktaviani, S. H. Nasution \& Sulistiono. 2008. Status keanekaragaman hayati sumberdaya perikanan perairan umum di Sulawesi. Balai Riset Perikanan Perairan Umum, Palembang.

Haryani, G. S \& P. E. Hehanussa. 2000. Preliminary studies of eel fish in lake Poso, Sulawesi Island, Indonesia. Re.Suwa. Hydrobiol. 12: p. 75-80.

Ishak, M. G. 2010. Konsep Penanganan Alur Di Belokan Dalam Rangka Pengelolaan Sungai Di Sulawesi Tengah. Media Litbang Sulteng III, (1): p. $01-05$.
Krismono. 2011. Penyelamatan ikan sidat di Danau Poso. Prosiding Forum Nasional Pemacuan Sumberdaya Ikan III. KSI 13. hal 1-8.

Krismono \& E.S. Kartamihardja. 2012. Konservasi dan Optimasi Pemanfaatan Stok Ikan Sidat (Anguilla spp.) di Das Poso, Sulawesi Tengah. J.Kebijak.Perikan.Ind. 4(1): 9-16.

Krismono, Mujiyanto, Y. Sugianti., M.R.A. Putri., A. Fitriyanto, B.I. Purnawati \& D. Sumarno. 2010. Pemacuan Stok Ikan Sidat Di Danau Poso. Laporan Akhir Riset Tahun 2010. BRPSI Jatiluhur Jawa Barat. $1 \mathrm{p}$.

Lehmusluoto, P \& B. Machbub. 1997. National Inventory of Major Lakes and Reservoirs of Indonesia (Revised eds). Expedition Indodanau Technical Report. 72 pp.

Muryanto, T \& D. Sumarno. 2013. Teknik pengamatan isi lambung ikan sidat (Anguilla marmorata) hasil tangkapan di Das Poso, Sulawesi Tengah. BTL.11(2): 51-56.

Naryadi. 2006. Strategi, teori dasar dan perkembangan. Lemhannas R.I., Jakarta: Lemhannas R.I.

Sarnita, A. 1973. Laporan Survey Perikanan Danau Lindu dan Poso. Laporan No. 58, Lembaga Penelitian Perikanan Darat, Bogor. 18 hal.

Samliok Ndobe. 2010. Struktur Ukuran Glass Eel Ikan Sidat (Anguilla Marmorata) di Muara Sungai Palu, Kota Palu, Sulawesi Tengah. Media Litbang Sulteng III. (2): p. 137-143.

Sugeha, H.Y., J. Aoyama \& K. Tsukamoto. 2008. Downstream Migration of TropicalAnguillid Silver Eels from lake Poso, Central Sulawesi Indonesia. Limnotek (13). 1 p.

Sutardjo \& Machfudz. 1974. Survey sidat di Danau Poso Sulawesi Tengah. Laporan No. 5. Bogor: Lembaga Penelitian Perikanan Darat.

Triyanto, Lukman \& I. Yuniarti. 2008. Bioekologi dan aspek penangkapan sidat (Anguilla spp.) di Perairan Poso, Sulawesi Tengah. Prosiding Seminar Nasional Limnologi IV LIPI. 570 pp. 